\title{
Biological Activity of C-Peptide on the Skin Microcirculation in Patients with Insulin-dependent Diabetes Mellitus
}

\author{
Thomas Forst, Thomas Kunt, Thomas Pohlmann, Kbrum Goitom, Martin Engelbach, Jürgen Beyer, and Andreas Pfützner \\ University Hospital Mainz, Department of Internal Medicine, Endocrinology and Metabolism, D-55101 Mainz, Germany
}

\begin{abstract}
19 insulin-dependent diabetes mellitus (IDDM) patients participated in a randomized double-blind crossover investigation to investigate the impact of human C-peptide on skin microvascular blood flow. The investigation was also carried out with 10 healthy volunteers. Blood pressure, heart rate, blood sugar, and $\mathrm{C}$-peptide levels were monitored during a 60-min intravenous infusion period of $\mathrm{C}$-peptide ( $8 \mathrm{pmol} \mathrm{kg}^{-1} \mathrm{~min}^{-1}$ ) or saline solution (154 mmol liter ${ }^{-1}$ $\mathrm{NaCl}$ ), and $30 \mathrm{~min}$ after stopping the infusion. During the same time period, capillary blood cell velocity (CBV), laser Doppler flux (LDF), and skin temperature were assessed in the feet. In the verum arm, C-peptide levels increased after starting infusion to reach a maximum of $2.3 \pm 0.2 \mathrm{nmol}$ liter ${ }^{-1}$ after $45 \mathrm{~min}$, but remained below 0.15 nmol liter $^{-1}$ during the saline treatment. Baseline CBV was lower in diabetic patients compared with healthy subjects (147 \pm 3.6 vs. $\left.162 \pm 4.2 \mu \mathrm{m} \mathrm{s}^{-1} ; P<0.01\right)$. During C-peptide administration, $\mathrm{CBV}$ in IDDM patients increased progressively from $147 \pm 3.6$ to $167 \pm 3.7 \mu \mathrm{m} \mathrm{s}^{-1} ; P<0.001$ ), whereas no significant change occurred during saline infusion or in healthy subjects. In contrast to the CBV measurements, the investigation of LDF, skin temperature, blood pressure, heart rate, or blood sugar did not demonstrate any significant change during the study.

Replacement of human C-peptide in IDDM patients leads to a redistribution in skin microvascular blood flow levels comparable to levels in healthy subjects by increasing the nutritive $\mathrm{CBV}$ relative to subpapillary arteriovenous shunt flow. (J. Clin. Invest. 1998. 101:2036-2041.) Key words: nutritive capillary blood flow • total skin blood flow • tissue nutrition $\bullet$ microvascular complications
\end{abstract}

\section{Introduction}

Numerous functional and structural microvascular disturbances have been reported for patients suffering from insulindependent diabetes mellitus (IDDM) ${ }^{1}(1-3)$. These microvas-

Address correspondence to Dr. Thomas Forst, University Hospital Mainz, Department of Internal Medicine and Endocrinology, Langenbeckstr. 1, D-55101 Mainz, Germany. Phone: 0049-6131-172639; FAX: 0049-6131-176619.

Received for publication 25 October 1997 and accepted in revised form 9 March 1998

1. Abbreviations used in this paper: $\mathrm{CBV}$, capillary blood cell velocity; IDDM, insulin-dependent diabetes mellitus; LDF, laser Doppler flux.

J. Clin. Invest.

(C) The American Society for Clinical Investigation, Inc. 0021-9738/98/05/2036/06 \$2.00

Volume 101, Number 10, May 1998, 2036-2041

http://www.jci.org cular abnormalities are thought to be involved in the development of various diabetic complications. Skin blood flow was found to be altered early after the diagnosis of diabetes and many of the functional disturbances appear to be reversible by improving metabolic control (4-6). The skin microcirculation is influenced by endothelial factors (7-9), the sympathetic nervous system $(10,11)$, and metabolic factors $(4,6)$, which may all deteriorate in the course of diabetic disease.

Normally, the major part of the overall skin blood flow is involved in thermoregulation and $<10 \%$ of the total skin blood flow passes through the skin capillaries to supply tissue nutrition (12-15). While total skin perfusion is increased in diabetes mellitus, there is some evidence for an impaired nutritional capillary blood cell velocity $(\mathrm{CBV})$ in diabetic patients $(13,14)$. This discrepancy between nutritional and total skin microcirculation has been explained by a shunting of blood through arteriovenous anastomosis (15).

C-Peptide, which is released from the pancreatic $\beta$ cell into the circulation in amounts equimolar with insulin, fulfills an important function in the assembly of the two-chain insulin structure but is otherwise considered to be biologically inactive. However, recent investigations involving experimental and human studies have suggested that $\mathrm{C}$-peptide might have vascular effects $(16,17)$ and the lack of endogenous $C$-peptide may be connected with the development of diabetic microvascular complications (18-20).

The aim of our investigation was to evaluate the impact of a short-term, systemic, continuous, C-peptide administration on total and nutritive skin microcirculation in the feet of IDDM patients.

\section{Methods}

Subjects. Microvascular blood flow was measured at the hallux of the feet in 19 insulin-dependent diabetic patients (10 male, 9 female; 13 nonsmoker, 6 smoker). Mean $( \pm \mathrm{SD})$ age and duration of diabetes were $36.9 \pm 8.6 \mathrm{yr}$ (range 22-52 yr) and $18.3 \pm 11.1 \mathrm{yr}$ (range 25-46 yr), respectively. Mean $\mathrm{HbA} 1 \mathrm{c}$ level was $6.7 \pm 0.9 \%$ (range $5.5-8.5 \%$; normal range: $4.5-6.5 \%$ ) and mean albuminuria was $36.6 \pm 57.7 \mathrm{mg}_{24} \mathrm{~h}^{-1}$

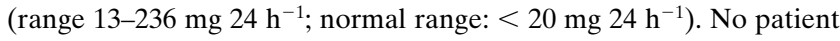
exhibited elevated plasma creatinine levels. Nine diabetic patients suffered from mild diabetic retinopathy, as assessed by nonmydriatic fundus photography (Canon CR 4-45-NM; Canon, Tokyo, Japan) and an examination by an ophthalmologist. Six diabetic patients had evidence of diabetic polyneuropathy as observed by cardiovascular reflex testing (Card II; Pro Sci, Linden, Germany) (21) and investigations of the vibration perception threshold (Vibra Tester 100; PHYWE, Göttingen, Germany) and the thermal perception threshold (Path-Tester; PHYWE) (22). The skin microvascular blood flow during intravenous infusion of C-peptide was also investigated in 10 healthy subjects ( 6 male, 4 female; 7 nonsmoker, 3 smoker). Mean age was $29.5 \pm 3.6 \mathrm{yr}$ (range 20-32 yr). All patients were clinically free from peripheral macrovascular disease, as evaluated by palpable foot pulses and segmental blood pressure measurements. Subjects were not included if they were on vasoactive drugs or on medications known to influence microvascular blood flow. No patient exhibited a blood glucose level $<4 \mathrm{mmol}$ liter $^{-1}$ at the start of the study, nor did 
they suffer from hypoglycemia before or during the investigation. All subjects refrained from smoking $2 \mathrm{~h}$ before the study. The study has been carried out in accordance with the Declaration of Helsinki (1989) by the World Medical Association. All subjects gave their informed consent to the protocol that had been approved by the local Ethics Committee.

Assessment of laser Doppler flux ( $L D F)$. The technique of laser Doppler fluxometry (MBF 3D; Moor Instruments, Devon, UK) was used to measure total skin microcirculation at the toe nailfold. The capillary component of superficial skin blood flow is physiologically minimal compared with the subpapillary blood flow. Therefore the LDF signal is largely indicative of thermoregulatory and subpapillary blood flow (23-25).

Videophotometric capillaroscopy. Using capillary microscopy it is possible to study the nutritional capillaries in the skin directly. This is a blood flow measuring technique allowing a direct estimate of nutritive CBV alone $(3,26)$. Nailfold capillaries of the hallux were displayed on a television monitor using a television microscope (Capi Scope; Moritex Europe Ltd., Cambridge, UK) at a magnification of 600. The image was stored on a videotape for subsequent analysis. 1-min flow was analyzed in each of eight previously recorded capillaries and the mean CBV was calculated from 10 measurements for each capillary. CBV was determined using the "line shift diagram method," a computerized video-photometric technique (Cap Image; Dr. Zeintl Software Engineering, Heidelberg, Germany). Using this method a scale is drawn adjacent to the blood vessel and the movement of plasma gaps is displayed in the form of vertical lines in a line shift diagram. The gradient of the lines in the diagram is determined and the velocity is calculated. The advantage of this method is that zero velocities and negative velocities can also be measured and calculated. The erythrocyte column width was measured at the arterial site of the capillary loops.

Other clinical investigations. Skin temperature of the toe was measured using an electronic thermometer (Digimed H11S; MedizinMesstechnik, Waldkirch, Germany). Systemic blood pressure and heart rate were measured at the right arm.

Test procedure. All subjects received C-peptide/saline infusions on two different occasions in a double-blind randomized order. The measurements were performed in a room with an ambient temperature of $21-24^{\circ} \mathrm{C}$. The subjects were allowed to lie down and to acclimatize for a period of $\sim 15 \mathrm{~min}$. The investigational procedure was started at $5 \mathrm{p} . \mathrm{m}$. after a fasting period of $5 \mathrm{~h}$. An intravenous catheter was placed into a superficial vein in the right arm for continuous infusion of either C-peptide ( $8 \mathrm{pmol} \mathrm{kg}^{-1} \mathrm{~min}^{-1}$ in $\mathrm{NaCl} 154 \mathrm{mmol} \mathrm{liter}^{-1}$; Eli Lilly Co., Indianapolis, IN) or placebo ( $\mathrm{NaCl} 154$ mmol liter $\left.^{-1}\right)$ for a period of $60 \mathrm{~min}$. A similar catheter was inserted into a vein in the left arm to enable blood sampling for the measurement of plasma glucose, C-peptide, and insulin levels.

Baseline measurements of LDF, CBV, skin temperature, systemic blood pressure, heart rate, blood sugar, and plasma C-peptide were made at the end of the acclimatization period. After starting C-peptide/saline infusion, the above described parameters were monitored every 15 min during the infusion period and $30 \mathrm{~min}$ after stopping the infusion.

Determination of blood glucose, C-peptide, and insulin levels. All serum samples were directly centrifuged at $-4^{\circ} \mathrm{C}$ and stored at $-40^{\circ} \mathrm{C}$ until subsequent analysis of hormone levels. Blood glucose was measured (Yellow Springs Instrument Co., Yellow Springs, OH). C-peptide and insulin levels were determined using commercially available radioimmunoassays (C-peptide: Linco human C-peptide RIA, Linco Research Inc., St. Charles, MO; insulin: insulin RIA, Diagnostic Products, Los Angeles, CA) as described in the literature (27). All measurements were performed as double determinations.

Statistical analysis. The results are expressed as the mean \pm SEM. Statistical analysis was performed using the Wilcoxon signed-rank test and the Mann-Whitney $U$ test was used to test differences between the groups. $P<0.05$ was considered to be statistically significant. Product moment correlation coefficient and linear regression analysis were performed to compare plasma C-peptide levels with LDF and CBV measurements.

\section{Results}

C-Peptide and insulin levels. In the diabetic group, plasma C-peptide levels increased substantially after starting the injection of C-peptide reaching a maximum of $2.3 \pm 0.2$ nmol liter $^{-1}$ $(P<0.001)$ but remaining below $0.15 \mathrm{nmol}^{\text {liter }}{ }^{-1}$ during infusion of the placebo. In the nondiabetic subjects, plasma C-peptide levels increased from 0.8 to $3.7 \mathrm{nmol} \mathrm{liter}^{-1}$ (Fig. 1). No changes were observed in insulin levels during the entire observation period. In addition, no significant differences could be detected between the different groups or treatment arms with regard to plasma insulin levels (Table I).

$C B V$. Compared with the control group, basal $\mathrm{CBV}$ was lower in diabetic patients before $\mathrm{NaCl}$ infusion $(148 \pm 4.0 \mathrm{vs}$. $\left.162 \pm 4.2 \mu \mathrm{m} \mathrm{s}^{-1} P<0.01\right)$ and before C-peptide infusion $\left(147 \pm 3.6\right.$ vs. $\left.162 \pm 4.2 \mu \mathrm{m} \mathrm{s}^{-1} ; P<0.01\right)$. During C-peptide infusion, $\mathrm{CBV}$ increased significantly in the diabetic group by $13.2 \%$ (from $147 \pm 3.6$ to $167 \pm 3.7 \mu \mathrm{m} \mathrm{s}^{-1} ; P<0.001$ ), reaching

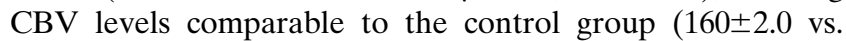
$157 \pm 3.4 \mu \mathrm{m} \mathrm{s}^{-1}$; NS). During saline infusion, CBV decreased by $2.4 \%$ in the diabetic group (from $147 \pm 3.6$ to $142 \pm 2.0 \mu \mathrm{m}$ $\mathrm{s}^{-1}$; NS; Fig. 2), and was significantly lower in comparison to CBV in healthy subjects during the whole investigation. In the diabetic group, the major difference in CBV between the $\mathrm{C}$-peptide and saline investigation was observed after $45 \mathrm{~min}$ until the end of the infusion period ( $P<0.0001$; Fig. 3 ). $30 \mathrm{~min}$ after the end of C-peptide administration, the CBV decreased to values not significantly different from basal $\mathrm{CBV}$ or $\mathrm{CBV}$ values during saline infusion. A positive relationship between plasma C-peptide levels and CBV was found in diabetic patients $(r=0.401 ; P<0.0001)$ but not in the healthy control group $(r=0.193 ; P=0.139)$.

The increase in CBV during C-peptide treatment was slightly larger in female subjects than in male subjects but not

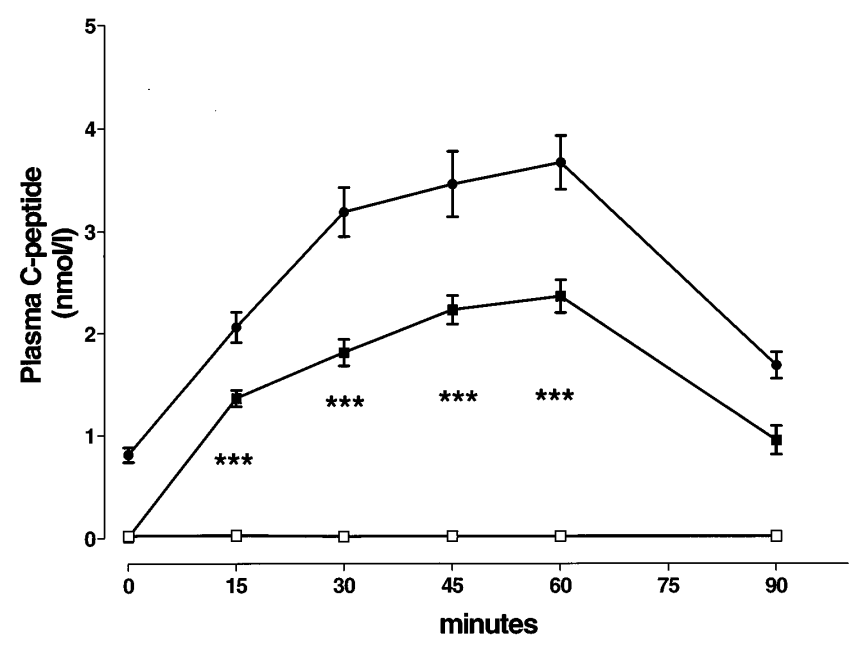

Figure 1. C-peptide plasma levels during the investigation (open boxes, IDDM/saline infusion; filled boxes, IDDM/C-peptide infusion; filled circles, healthy subjects/C-peptide infusion; $P, \mathrm{C}$-peptide vs. $\mathrm{NaCl}$ infusion in IDDM; $* * * P<0.0001)$. 
Table I. Heart Rate, Blood Pressure, Blood Glucose, Plasma Insulin Levels, and Skin Temperature in IDDM Patients during $C$-Peptide or Saline Infusion and in Healthy Subjects during C-Peptide Infusion (Mean \pm SEM)

\begin{tabular}{|c|c|c|c|c|c|c|c|}
\hline & & & & Infus & eriod & & \\
\hline & & Basal & $15 \mathrm{~min}$ & $30 \mathrm{~min}$ & $45 \mathrm{~min}$ & $60 \mathrm{~min}$ & $90 \mathrm{~min}$ \\
\hline Heart rate & C-Peptide & $69 \pm 2.7$ & $66 \pm 2.4$ & $67 \pm 2.5$ & $65 \pm 2.3$ & $65 \pm 2.2$ & $66 \pm 2.3$ \\
\hline (bpm) & Saline & $70 \pm 1.7$ & $70 \pm 1.2$ & $68 \pm 1.4$ & $68 \pm 1.8$ & $68 \pm 1.6$ & $67 \pm 1.3$ \\
\hline & Healthy control & $74 \pm 2.4$ & $67 \pm 2.3$ & $68 \pm 2.4$ & $65 \pm 2.1$ & $65 \pm 2.1$ & $64 \pm 2.0$ \\
\hline Systolic RR & C-Peptide & $115 \pm 2.3$ & $119 \pm 2.2$ & $120 \pm 2.3$ & $117 \pm 1.9$ & $117 \pm 1.6$ & $119 \pm 2.6$ \\
\hline$(\mathrm{mmHg})$ & Saline & $130 \pm 2.6$ & $125 \pm 2.7$ & $120 \pm 3.2$ & $119 \pm 3.0$ & $117 \pm 3.1$ & $119 \pm 3.1$ \\
\hline & Healthy control & $126 \pm 1.6$ & $117 \pm 2.1$ & $121 \pm 1.4$ & $118 \pm 1.3$ & $114 \pm 1.2$ & $115 \pm 1.5$ \\
\hline Diastolic RR & C-Peptide & $82 \pm 1.5$ & $78 \pm 1.2$ & $79 \pm 1.5$ & $79 \pm 1.7$ & $80 \pm 1.6$ & $80 \pm 1.7$ \\
\hline$(\mathrm{mmHg})$ & Saline & $83 \pm 1.5$ & $81 \pm 2.1$ & $79 \pm 2.0$ & $79 \pm 2.0$ & $79 \pm 1.9$ & $78 \pm 2.5$ \\
\hline & Healthy control & $83 \pm 1.9$ & $81 \pm 1.6$ & $80 \pm 1.7$ & $80 \pm 1.2$ & $78 \pm 1.5$ & $77 \pm 1.9$ \\
\hline Blood glucose & C-Peptide & $6.3 \pm 0.5$ & $6.6 \pm 0.5$ & $6.7 \pm 0.6$ & $6.7 \pm 0.6$ & $6.6 \pm 0.6$ & $6.5 \pm 0.6$ \\
\hline$\left(\mathrm{mmol} \mathrm{dl}^{-1}\right)$ & Saline & $7.7 \pm 0.9$ & $7.5 \pm 0.8$ & $7.5 \pm 0.8$ & $7.4 \pm 0.8$ & $7.2 \pm 0.8$ & $7.4 \pm 0.7$ \\
\hline & Healthy control & $5.1 \pm 0.2$ & $5.2 \pm 0.2$ & $5.1 \pm 0.2$ & $4.8 \pm 0.2$ & $5.2 \pm 0.2$ & $4.9 \pm 0.1$ \\
\hline Plasma insulin & C-Peptide & $175.8 \pm 42.6$ & $156.6 \pm 35.4$ & $148.2 \pm 36.0$ & $168.6 \pm 36.6$ & $150.6 \pm 33.0$ & $151.2 \pm 36.0$ \\
\hline$\left(\right.$ pmol liter $\left.^{-1}\right)$ & Saline & $190.8 \pm 34.2$ & $172.2 \pm 31.2$ & $165.0 \pm 37.8$ & $148.8 \pm 34.8$ & $165.0 \pm 40.2$ & $165.6 \pm 45.0$ \\
\hline & Healthy control & $162.5 \pm 22.6$ & $117.8 \pm 19.2$ & $147.7 \pm 23.6$ & $131.8 \pm 27.6$ & $127.1 \pm 20.0$ & $123.6 \pm 18.9$ \\
\hline Skin temperature & C-Peptide & $28.6 \pm 0.4$ & $28.3 \pm 0.5$ & $28.4 \pm 0.5$ & $28.3 \pm 0.5$ & $28.2 \pm 0.6$ & $24.7 \pm 0.6$ \\
\hline$\left({ }^{\circ} \mathrm{C}\right)$ & Saline & $28.3 \pm 0.4$ & $28.1 \pm 0.5$ & $28.3 \pm 0.6$ & $28.2 \pm 0.6$ & $28.1 \pm 0.6$ & $27.3 \pm 0.6$ \\
\hline & Healthy control & $27.1 \pm 0.5$ & $27.0 \pm 0.7$ & $27.0 \pm 0.7$ & $26.8 \pm 0.8$ & $26.5 \pm 0.9$ & $26.7 \pm 0.7$ \\
\hline
\end{tabular}

sufficient to be statistically significant (10.2 vs. $16.4 \%$, respectively). A slight relationship could be observed between the increase in CBV and the amount of albuminuria $(r=0.47 ; P<$ $0.05)$, whereas no relationship could be detected between the increase in $\mathrm{CBV}$ and age $(r=0.16 ; P=0.24)$, duration of diabetes $(r=0.15 ; P=0.27)$, HbA1c $(r=0.12 ; P=0.32)$, or the presence of diabetic retinopathy or neuropathy.

The erythrocyte column width did not change during the investigation, during C-peptide infusion (from $8.9 \pm 0.34$ to $8.8 \pm 0.22 \mu \mathrm{m}$; NS), or during saline infusion (from $9.2 \pm 0.32$ to $8.9 \pm 0.19 \mu \mathrm{m} ; \mathrm{NS})$.
$L D F$. Basal LDF measurements were slightly lower in the control group as compared with the IDDM group (37.1 \pm 7.1 vs. $62.9 \pm 12.5 ; P<0.05)$. In contrast to the increase in CBV seen in diabetic patients during C-peptide administration, the values of the LDF did not exhibit any consistent change during C-peptide infusion or placebo infusion at any point in time during the investigation (Fig. 4).

Blood pressure, heart rate, blood glucose levels, and skin temperature measurements at the toe are shown in Table I. No significant change in these parameters could be observed during the study.

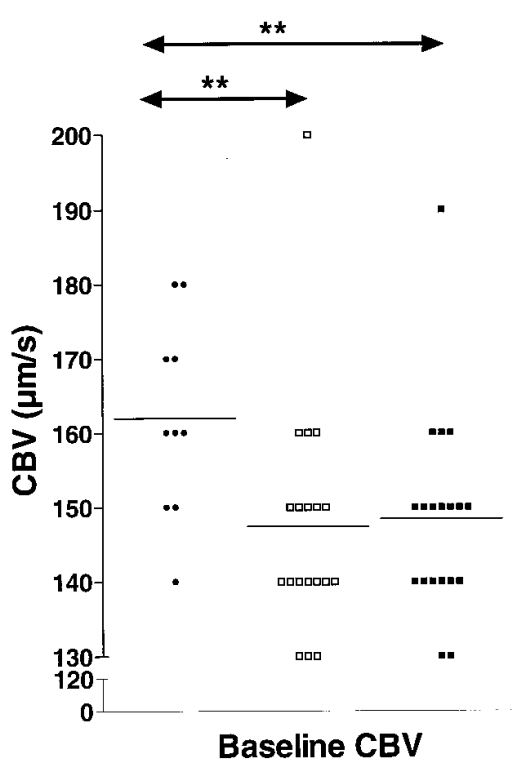

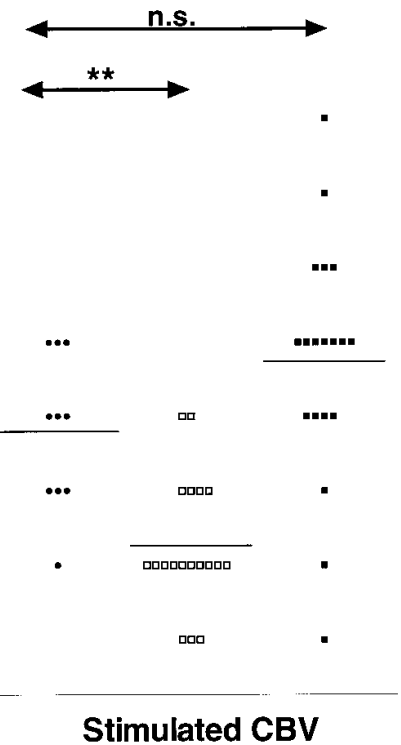

Figure 2. Baseline CBV and CBV during C-peptide or placebo infusion (open boxes, IDDM/saline infusion; filled boxes, IDDM/C-peptide infusion; filled circles, healthy subjects/C-peptide infusion; $P$, versus healthy subjects; $* * P<0.01)$. 


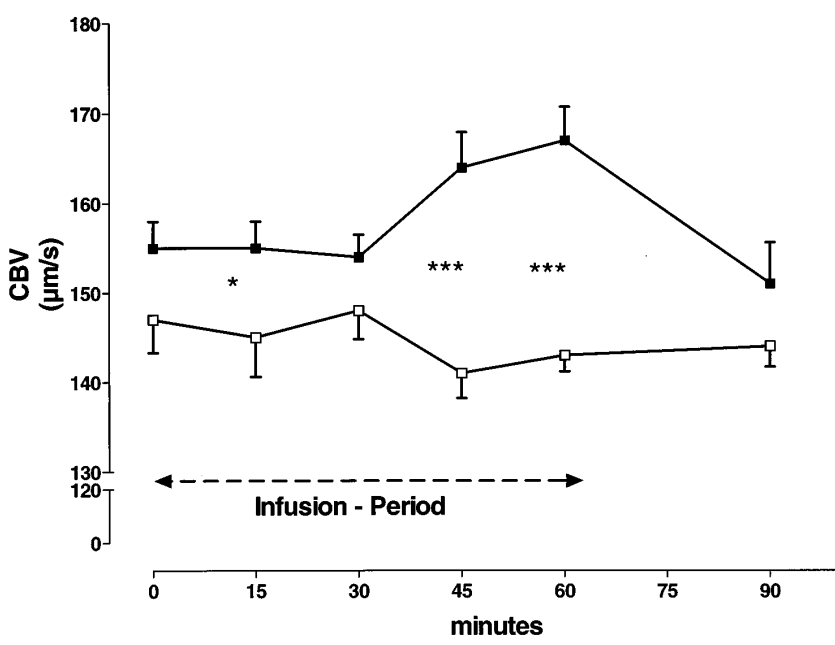

Figure 3. CBV during the investigation (open boxes, IDDM/saline infusion; filled boxes, IDDM/C-peptide infusion; $P, \mathrm{C}$-peptide vs. $\mathrm{NaCl}$ infusion in IDDM; $* P<0.05 ; * * * P<0.0001)$.

\section{Discussion}

Microvascular disturbances contribute to a large proportion of the diabetic late complications. Numerous microvascular functional changes occur soon after the diagnosis of the metabolic disease including increased blood flow $(28,29)$, increased vascular permeability (30), an impaired neurogenic vascular response $(31,32)$, limitation of hyperemia (33), impaired peripheral vasomotion $(34,35)$, and an increased intracapillary pressure (36). These functional microvascular abnormalities may precede structural changes in the later course of microvascular disease (37) and may be implicated in the development of trophic tissue damage $(2,6,28)$.

The capillary circulation is functionally situated in parallel to the arteriovenous shunts and is thought to have the primary function of skin nutrition. It has been estimated that $80-90 \%$ of total skin blood flow passes through thermoregulatory arte-

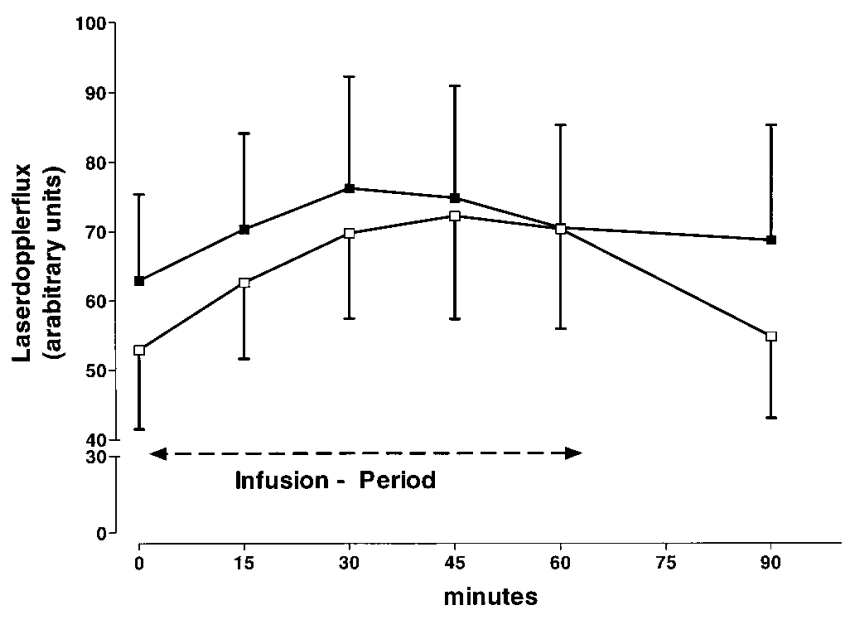

Figure 4. LDF during the investigation (open boxes, IDDM/saline infusion; filled boxes, IDDM/C-peptide infusion). riovenous shunts and does not enter the capillary bed (12). The observations on the nutritive component of skin blood flow in diabetic patients are confusing. While most studies have shown an impaired $\operatorname{CBV}(13,14,38,39)$, other reports describe either an inconspicuous (29) or increased CBV (32) in the skin of diabetic patients.

Since the 1970s C-peptide measurements have been used extensively in the clinical evaluation of residual insulin secretion in diabetic patients. Residual insulin secretion in IDDM patients has been suggested to be associated with a slower progression of diabetic microvascular complications (40). A negative relationship, which is greater than the association between glycemic control and early retinopathy, has been demonstrated between endogenous $\beta$ cell activity and early signs of diabetic retinopathy (41). Therefore, it may be considered that C-peptide rather than insulin exerts a beneficial effect on microvascular retinal changes. After combined kidney and pancreas transplantation in IDDM patients, CBV increased during both rest and reactive hyperemia $(39,42)$. In addition, in non-insulin-dependent diabetes mellitus patients an inverse relationship was found between remaining C-peptide levels and the development of diabetic polyneuropathy (43). In animal experiments, C-peptide has been shown to prevent diabetes- and hyperglycemia-induced vascular and neural dysfunction (17). From other studies it can be concluded that C-peptide, when given to IDDM patients, has the potency to improve membrane function in glomeruli cells $(20,44)$, to diminish the leakage of fluorescein across the blood retinal barrier (20), to stimulate oxygen uptake and blood flow in working skeletal muscle (16), and to improve autonomic nerve function (19).

In IDDM patients, the destruction of the pancreatic $\beta$ cells usually leads to a complete failure of endogenous insulin and C-peptide secretion. In our investigation, continuous intravenous administration of human C-peptide ( $8 \mathrm{pmol} / \mathrm{kg} / \mathrm{min})$ over a period of $60 \mathrm{~min}$ in IDDM patients without any substantial endogenous C-peptide production resulted in plasma C-peptide levels that were in the range of those found in the postprandial state of healthy subjects $(45,46)$.

Comparable to earlier investigations $(13,14,38,39)$, we observed an decreased CBV in IDDM patients compared with healthy subjects. The increase in plasma C-peptide levels was associated with an increase in nutritional CBV; however, it did not affect total skin blood flow in IDDM patients. These findings suggest a redistribution of skin microvascular blood flow into the nutritive capillary circulation during C-peptide administration. Thus, the increase in CBV may improve the exchange of nutrients, oxygen, and waste products in the skin. Our results may also explain the observed increase in oxygen uptake and glucose metabolism in skeletal muscle in IDDM patients during C-peptide administration $(16,44)$.

The most striking observation in this study was the increase in CBV after the infusion of human C-peptide without affecting total skin blood flow. In healthy subjects, peak C-peptide levels are usually seen after the ingestion of food with a complementary increase of glucose and nutrients in the blood stream. The postprandial distribution of microvascular blood flow into nutritive vascular compartments may fulfill physiological requirements and the lack of endogenous C-peptide may lead to disturbances in nutritive tissue metabolism.

So far, the mechanism of this microvascular action of human C-peptide is not known. Although a specific C-peptide re- 
ceptor has not been identified in human cells, Flatt et al. have found evidence for a specific binding of C-peptide in cultured $\beta$ cells of the rat (47). In addition, $C$-peptide has been shown to stimulate renal $\mathrm{Na}^{+}, \mathrm{K}^{+}$-ATPase activity with the subsequent activation of calcium-dependent intracellular signaling pathways in the rat renal tubular cell (48). Disturbances in $\mathrm{Na}^{+}, \mathrm{K}^{+}$ATPase activity have been demonstrated in several tissues of diabetic patients and may be involved in the alteration of the contractile response to hormones and neurotransmitters in the vascular smooth muscle $(49,50)$.

Insulin has been shown to increase skin CBV $(51,52)$, which might be influenced by the modulation of endotheliumderived vasoactive substances, such as endothelin, nitric oxide, or adenosine (53). However, there were no significant differences in the insulin levels between the different groups and observation periods and, therefore, the observed effects on microvascular blood flow may be attributed to the changes in C-peptide levels. It may be assumed that the effect of C-peptide is also mediated via endothelium-derived vasoactive mediators.

In conclusion, replacement of human C-peptide possesses microcirculatory effects that redistribute microvascular blood flow in favor of nutritive CBV in IDDM patients. Further research is necessary to evaluate the underlying mechanisms and the therapeutic significance of the observed findings on microvascular complications in IDDM.

\section{Acknowledgments}

We thank the nurses and staff of the Department of Endocrinology of the University Hospital Mainz for their assistance. We acknowledge Mirjam Löbig and Nur Abdollahnia for excellent technical assistance and Mr. Ronald Chance (Eli Lilly) for the careful revision of the manuscript. This paper includes data from the thesis of Thomas Pohlmann.

This study was supported by a grant provided by Eli Lilly and Company.

\section{References}

1. Tooke, J.E. 1995. Microvascular function in human diabetes. Diabetes. 44:721-726.

2. Rendell, M., and B.S. Ola Bemisedun. 1992. Diabetic cutaneous microangiopathy. Am. J. Med. 93:611-618.

3. Shami, S.K., and S.J. Chittenden. 1991. Microangiopathy in diabetes mellitus. II. Features complications and investigation. Diabetes Research. 17:157168.

4. Tooke, J.E., P.E. Lins, J. Ostergren, and B. Fagrell. 1985. Skin microvascular autoregulatory responses in type 1 diabetes: the influence of duration and control. Int. J. Microcirc. Clin. Exp. 4:249-256.

5. Ewald, U., T. Tuvemo, and G. Rooth. 1981. Early reduction of vascular reactivity in diabetic children detected by transcutaneous oxygen electrode. Lancet. I:1287-1288.

6. Flynn, M.D., and J.E. Tooke. 1992. Aetiology of diabetic foot ulceration: a role for the microcirculation? Diabetic Med. 8:320-329.

7. Smits, P., J.A. Kapma, M.C. Jacobs, J. Luttermann, and T. Thien. 1993. Endothelium-dependent vascular relaxation in patients with type 1 diabetes. Diabetes. 42:148-153.

8. Panza, J.A., A.A. Quyyumi, J.E. Brush, and S.E. Epstein. 1990. Abnormal endothelium-dependent vascular relaxation in patients with essential hypertension. N. Engl. J. Med. 323:22-27.

9. McNally, P.G., P.A.C. Watt, T. Rimmer, A.C. Burden, J.R. Hearnshaw, and H. Thurston. 1994. Impaired contraction and endothelium dependent relaxation in isolated resistance vessels from patients with insulin-dependent diabetes mellitus. Clin. Sci. 87:31-36.

10. Watkins, P.J., and M.E. Edmonds. 1983. Sympathetic nerve failure in diabetes. Diabetologia. 25:73-77.

11. Stevens, M.J., M.E. Edmonds, A.V.M. Foster, S.L.E. Douglas, and P.J. Watkins. 1992. Paradoxical blood flow responses in the diabetic neuropathic foot: an assessment of the contribution of vascular denervation and microangiopathy. Diabetic Med. 9:49-54.

12. Coffmann, J.D. 1972. Total and nutritive blood flow in the finger. Clin. Sci. 42:243-250.

13. Jörneskog, G., K. Brismar, and B. Fagrell. 1995. Skin capillary circulation is more impaired in the toes of diabetic than non-diabetic patients with peripheral vascular disease. Diabetic Med. 12:36-41.

14. Jörneskog, G., K. Brismar, and B. Fagrell. 1995. Skin capillary circulation severely impaired in toes of patients with IDDM, with and without late diabetic complications. Diabetologia. 38:474-480.

15. Boulton, A.J.M., J.H.B. Scarpello, and J.D. Ward. 1982. Venous oxygenation in the diabetic neuropathic foot: evidence of arteriovenous shunting? Diabetologia. 22:6-8.

16. Johansson, B.L., B. Linde, and J. Wahren. 1992. Effects of C-peptide on blood flow, capillary diffusion capacity and glucose utilization in the exercising forearm of type 1 (insulin-dependent) diabetic patients. Diabetologia. 35:11511158 .

17. Ido, Y., A. Vindigni, K. Chang, L. Stramm, R. Chance, W.F. Heath, R.D. DiMarchi, E. Di Cera, and J.R. Williamson. 1997. Prevention of vascular and neural dysfunction in diabetic rats by C-peptide. Science. 277:563-566.

18. Wahren, J., B.L. Johansson, and H. Wallberg-Henriksson. 1994. Does C-peptide have a physiological role? Diabetologia. 37(Suppl. 2):99-107.

19. Johansson, B.L., K. Borg, E. Fernqvist-Forbes, T. Odergren, S. Remahl, and J. Wahren. 1996. C-peptide improves autonomic nerve function in IDDM patients. Diabetologia. 39:687-695.

20. Johansson, B.L., A. Kernell, S. Sjöberg, and J. Wahren. 1993. Influence of combined C-peptide and insulin administration on renal function and metabolic control in diabetes type 1. J. Clin. Endocrinol. Metab. 77:976-981.

21. Ziegler, D., G. Laux, K. Dannehl, M. Spüler, H. Mühlen, P. Mayer, and F.A. Gries. 1992. Assessment of cardiovascular autonomic function: age-related normal ranges and reproducibility of spectral analysis, vector analysis, and standard tests of heart rate variation and blood pressure response. Diabetic Med. 9: $166-175$.

22. Claus, D., C. Mustafa, W. Vogel, M. Herz, and B. Neundörfer. 1993. Assessment of diabetic neuropathy: definition of norm and discrimination of abnormal nerve function. Muscle Nerve. 16:757-768.

23. Rendell, M., T. Bergmann, G. O'Donnell, E.D. Drobny, J. Borgos, and R.F. Bonner. 1989. Microvascular blood flow, volume, and velocity measured by laser Doppler techniques in IDDM. Diabetes. 38:819-824.

24. Bircher, A., E.M. de Boer, T. Agner, J.E. Wahlberg, and J. Serup. 1994. Guidelines for measurement of cutaneous blood flow by laser Doppler flowmetry. Contact Dermatitis. 30:65-72.

25. Forst, T., A. Pfützner, M. Arin, R. Bauersachs, B. Bach, H. Biehlmaier, E. Küstner, and J. Beyer. 1997. Effect of transcutaneous electrical nerve stimulation on total skin microcirculation in the diabetic foot. J. Diabetic Complications. 11:291-297.

26. Tooke, J.E. 1993. Methodologies used in the study of the microcirculation in diabetes mellitus. Diabetes Metab. Rev. 9:57-70.

27. Morgan, C.R., and A. Lazarow. 1963. Immunoassay for insulin: two antibody system. Plasma insulin levels in normal, subdiabetic and diabetic rats. Diabetes. 12:115-119.

28. Corbin, D.O.C., R.J. Young, D.C. Morrison, P. Hoskins, W.N McDicken, E. Housley, and B.F. Clarke. 1987. Blood flow in the foot, polyneuropathy and foot ulceration in diabetes mellitus. Diabetologia. 30:468-473.

29. Flynn, M.D., M.E. Edmonds, J.E. Tooke, and P.J. Watkins. 1988. Direct measurement of capillary blood flow in the diabetic neuropathic foot. Diabetologia. 31:652-656.

30. Bollinger, A., J. Frey, K. Jäger, J. Furrer, J. Seglias, and W. Siegenthaler. 1982. Patterns of diffusion through skin capillaries in patients with long term diabetes. N. Engl. J. Med. 307:1305-1310.

31. Walmsley, D., and P.G. Wiles. 1991. Early loss of neurogenic inflammation in the human diabetic foot. Clin. Sci. 80:605-610.

32. Netten, P.M., H. Wollersheim, T. Thien, and J.A. Luttermann. 1996. Skin microcirculation of the foot in diabetic neuropathy. Clin. Sci. 91:559-565.

33. Rayman, G., S.A. Williams, P.D. Spencer, L.H. Smaje, P.H. Wise, and J.E. Tooke. 1986. Impaired microvascular hyperaemic response to minor skin trauma in type I diabetes. Clin. Res. 292:1295-1298.

34. Stansberry, K.B., S.A. Shapiro, M.A. Hill, P.M. McNitt, M.D. Meyer, and A.I. Vinik. 1996. Impaired peripheral vasomotion in diabetes. Diabetes Care. 19:715-721.

35. Benbow, S.J., D.W. Pryce, K. Noblett, I.A. MacFarlane, P.S. Friedmann, and G. Williams. 1995. Flow motion in peripheral diabetic neuropathy. Clin. Sci. 88:191-196.

36. Sandemann, D.D., A.C. Shore, and J.E. Tooke. 1992. Relation of skin capillary pressure in patients with insulin-dependent diabetes mellitus to complications and metabolic control. N. Engl. J. Med. 327:760-764.

37. Rayman, G., R.A. Malik, A.K. Sharma, and J.L. Day. 1995. Microvascular response to tissue injury and capillary ultrastructure in the foot skin of type I diabetic patients. Clin. Sci. 89:467-474.

38. Jörneskog, G., J. Östergren, G. Tyden, J. Bolinder, and B. Fagrell. 1987. Is skin microvasculature reactivity improved in diabetes after pancreas and kidney transplantation? Int. J. Microcirc. Clin. Exp. 43:203-210. 
39. Jörneskog, G., G. Tyden, J. Bolinder, and B. Fagrell. 1990. Does combined kidney and pancreas transplantation reverse functional diabetic microangiopathy? Transplant. Int. 3:167-170.

40. Sjöberg, S., R. Gunnarsson, M. Gjötterberg, M. Persson, and J. Östman. 1987. Residual insulin production and prevalence of microvascular lesions and polyneuropathy in long term type 1 (insulin-dependent) diabetes mellitus. Diabetologia. 30:208-213.

41. Kernell, A., J. Ludvigsson, and K. Finnström. 1990. Vitreous fluorophotometry in juvenile diabetics with and without retinopathy in relation to metabolic control: insulin antibodies and C-peptide levels. Acta Ophthalmolgica. 68: 415-420.

42. Jörneskog, G., G. Tyden, J. Bolinder, and B. Fagrell. 1991. Skin microvascular reactivity in fingers of diabetic patients after combined kidney and pancreas transplantation. Diabetologia. 34(Suppl. 1):135-137.

43. Partanen, J., L. Niskanen, J. Lehtinen, E. Mervaala, O. Sitonen, and M. Uusitupa. 1995. Natural history of peripheral neuropathy in patients with noninsulin dependent diabetes mellitus. N. Engl. J. Med. 333:89-94.

44. Johansson, B.L., S. Sjöberg, and J. Wahren. 1992. The influence of human C-peptide on renal function and glucose utilisation in type 1 (insulin dependent) diabetic patients. Diabetologia. 35:121-128.

45. Hoogwerf, B.J., J.J. Barbosa, J.P. Bantle, D. Daine, and F.C. Goetz. 1983. Urinary C-peptide as a measure of beta cell function after a mixed meal in healthy subjects: comparison of four hour urine C-peptide with serum insulin and plasma C-peptide. Diabetes Care. 6:488-492.
46. Horwitz, D.L., J.I. Starr, M.E. Mako, W.G. Blackard, and A.H. Rubenstein. 1975. Proinsulin, insulin, and C-peptide concentrations in human portal and peripheral blood. J. Clin. Invest. 55:1278-1283.

47. Flatt, P.R., S.K. Swanstonn-Flatt, S.M. Hampton, C.J. Bailey, and V. Marks. 1986. Specific binding of the C-peptide of proinsulin to cultured B-cells from a transplantable rat islet cell tumor. Biosci. Rep. 6:193-199.

48. Ohtomo, Y., A. Aperia, B. Sahlgren, B.L. Johansson, and J. Wahren. 1996. C-peptide stimulates rat renal tubular $\mathrm{Na}^{+}, \mathrm{K}^{+}$-ATPase activity in synergism with neuropeptide Y. Diabetologia. 39:199-205.

49. Greene, D.A., S.A. Lattimer, and A.A.F. Sima. 1987. Sorbitol, phosphoinositides, and sodium-potassium-ATPase in the pathogenesis of diabetic complications. N. Engl. J. Med. 316:599-600.

50. Scarpini, E., R. Bianchi, M. Moggio, M.G. Fiori, and G. Scarlato. 1993. Decrease of nerve $\mathrm{Na}^{+}, \mathrm{K}^{+}$-ATPase in the pathogenesis of human diabetic neuropathy. J. Neurol. Sci. 120:159-167.

51. Tooke, J.E., P.E. Lins, J. Östergren, U. Adamson, and B. Fagrell. 1985. The effect of intravenous insulin infusion on skin microcirculatory flow in type 1 diabetes. Int. J. Microcirc. 4:69-83.

52. Flynn, M.D., M. Boolell, J.E. Tooke, and P.J. Watkins. 1992. The effect of insulin infusion on capillary blood flow in the diabetic neuropathic foot. Diabetic Med. 9:630-634.

53. Poldermann, K.H., C.D.A. Stehhouwer, G.J. van Kamp, and L.J.G. Gooren. 1996. Effects of insulin infusion on endothelium-derived vasoactive substances. Diabetologia. 39:1284-1292. 